\title{
A Karyomorphological Study of Five Species and One Variety of Cycas*
}

\author{
Katsuhiko Kondo', Goro Kokubugata', Masahiro Hizume ${ }^{2}$, \\ Ryuso Tanaka ${ }^{1}$ and Toshihiko Satake ${ }^{3}$ \\ 'Laboratory of Plant Chromosome and Gene Stock, Faculty of Science, \\ Hiroshima University, Higashi-Hiroshima 739, Japan \\ ${ }^{2}$ Biological Institute, Faculty of Education, Ehime University, Matsuyama 790, Japan \\ ${ }^{3}$ Satake Corporation, Higashi-Hiroshima 739, Japan
}

Accepted April 29, 1995

Cycas, the Cycadaceae, is distributed in the tropical to subtropical regions in Asia, Africa and Australia and consists of eight species (Schuster 1932). Since Cycas is considered the most primitive genus among the cycads (Stevenson 1990), it could be a key genus for the study of cycad phylogeny to justify and clarify the genetic and species relationships among the cycad members.

Chromosomal, phylogenetic and evolutional relationships of general cycad species other than Cycas species have been previously well-studied by Marchant (1968) and Moretti (1990). Chromosome numbers of three species of Cycas have been reported by Sax and Beal (1934) and Selvaraj (1980). Chromosomal phylogeny of Cycas, however, are poorly characterized in most standard references, especially with respect to karyomorphological details.

\section{Materials and methods}

The materials studied are shown in Table 1. Taxonomical treatment of Cycas followed Schuster (1932). Cycas circinalis L., C. rumphii Miq., C. revoluta Thunberg var. revoluta and C. revoluta var. taiwaniana (Carruth.) Schuster were cultivated in the greenhouse of Laboratory of Plant Chromosome and Gene Stock, Faculty of Science, Hiroshima University. Cycas media R. Brown var. basaltica (Gardner) Schuster was cultivated in the greenhouse of Satake Corporation and C. siamensis Miq. was cultivated in the greenhouse of Hiroshima Botanical Garden.

Young leaflets of the five species and one variety of Cycas were harvested and chopped into ca. $2 \mathrm{~mm}$ diameter, and were pretreated in $2 \mathrm{mM}$ 8-hydroxyquinoline at $4^{\circ} \mathrm{C}$ for $8 \mathrm{hr}$. Then, they were fixed in acetic ethanol $(1: 3)$ at $4^{\circ} \mathrm{C}$ for $24 \mathrm{hr}$ and were stored in $70 \%$ ethanol at $-20^{\circ} \mathrm{C}$. After they were sorked in distilled water and then $45 \%$ acetic acid for $10 \mathrm{~min}$, they were macerated in $45 \%$ acetic acid at $60^{\circ} \mathrm{C}$ for $5 \mathrm{~min}$. Some small-pieces of leaflets of $C$. revoluta var. revoluta were macerated in enzymatic mixture of $2 \%$ cellulase Onozuka RS (Yakult) and $1 \%$ pectolyase Y-23 (Seishin) in distilled water (w/v) at $36^{\circ} \mathrm{C}$ for one hour. Effects of the maceration in $45 \%$ acetic acid and the enzymatic solution on chromosome length and arm ratio were examined by $t$-test $(\mathrm{p}<0.05)$. Since all of the chromosomes showed no significant differences in mean arm ratio and chromosome length, $45 \%$ acetic acid and the enzymatic solution were used alternatively for maceration of Cycas leaflets. The macerated pieces of leaflets were placed on glass-slides, and were stained in $1 \%$ aceto-orcein at room temperature for $4 \mathrm{hr}$. The preparations were made with $1 \%$ aceto-orcein by the squash method.

* This paper is of the contribution no. 39 from Laboratory of Plant Chromosome and Gene Stock, Faculty of Science, Hiroshima University. 
Table 1. Comparison of chromosomes in five species and one variety of Cycas

\begin{tabular}{|c|c|c|c|c|c|c|}
\hline \multirow{2}{*}{ Species } & \multirow{2}{*}{ Interphase chromosome } & \multirow{2}{*}{$\begin{array}{l}\text { Mitotic prophase } \\
\text { chromosome }\end{array}$} & \multicolumn{4}{|c|}{ Karyotype } \\
\hline & & & $\mathbf{m}$ & sm & st & $t$ \\
\hline \multicolumn{7}{|l|}{ Sect. Lemuricae } \\
\hline \multicolumn{7}{|l|}{ Subsect. Pandemicae } \\
\hline C. circinalis & Complex chromocenter type & Interstitial type & 6 & 2 & 2 & 12 \\
\hline C. rumphii & Complex chromocenter type & Interstitial type & 4 & 3 & 3 & 12 \\
\hline Subsect. Endemicae & & & & & & \\
\hline C. media var. basaltica & Complex chromocenter type & Interstitial type & 5 & 5 & 0 & 12 \\
\hline \multicolumn{7}{|l|}{ Sect. Indo-sinenses } \\
\hline C. siamensis & Complex chromocenter type & Interstitial type & 4 & 6 & $\mathbf{0}$ & 12 \\
\hline \multicolumn{7}{|l|}{ Sect. Asiorientales } \\
\hline C. revoluta var. revoluta & Complex chromocenter type & Interstitial type & 4 & 6 & $\mathbf{0}$ & 12 \\
\hline C. revoluta var, taiwaniana & Complex chromocenter type & Interstitial type & 2 & 8 & 0 & 12 \\
\hline
\end{tabular}

$\mathrm{m}=$ median-centromeric chromosome. $\mathrm{sm}=$ submedian-centromeric chromosome. $\mathbf{s t}=$ subterminal-centromeric chromosome. $t=$ terminal-centromeric chromosome.

Chromosomes at early interphase isolated by mean of two nuclei placed side by side and the contour of those cells supposed immediacy after a somatic division, mitotic prophase defined by chromosomes remaining oblong-shape were observed. Chromosome numbers counted and lengths of long and short arms were measured at mitotic metaphase defined by chromosomes separated from each other.

Morphological classification of chromosomes at interphase and mitotic prophase followed Tanaka (1977). The chromosomes of each complement at mitotic metaphase were aligned in order of chromosome length from the longest to the shortest chromosomes. At least three chromosome complements at mitotic metaphase were measured to obtain mean arm ratio calculated by long arm length/short arm length. Chromosomes were classified according to centromeric positions defined with mean arm ratios (Levan et al. 1964). Additionally, average of total length of the chromosomes of the complement in each of the five species and one variety of Cycas was calculated.

\section{Results and discussion}

Five species and one variety of Cycas showed commonly the complex chromocenter type of the chromosomes at early interphase. Partial to whole region of the nucleus of the six taxa at early interphase was darkly stained (Fig. 1A-F, Table 1). They also showed commonly the interstitial type of the chromosomes at mitotic prophase, which indicated darkly-stained heterochromatins to tend in some portions to form clusters (Fig. 2A-F, Table 1). Those heterochromatins could correspond to the chromocenters at interphase since their distribution patterns were similar to each other in every taxon. Thus, the taxa of Cycas studied displayed morphologically quite similar chromosomes at early interphase and mitotic prophase.

Five species and one variety of Cycas showed the chromosome number of $2 n=22$ (Fig. 3 ). The chromosome numbers of $C$. circinalis and $C$. rumphii documented here verified those reported by Sax and Beal (1934), and those of C. revoluta var. taiwaniana verified those reported by Peng et al. (1986). In contrast, the present chromosome count of $2 n=22$ in $C$. revoluta var. revoluta (Fig. 3E) verified that reported by Sax and Beal (1934), but differed from the chromosome count of $2 n=24$ reported by Ishikawa (1916) and from the chromosome counts of $2 n=20,22$ and 24 reported by Selvaraj (1980).

The karyotypes of five species and one variety of Cycas based on the data of mean arm ratios were tabulated in Table 2 . They exhibited commonly 12 terminal-centromeric chromo- 


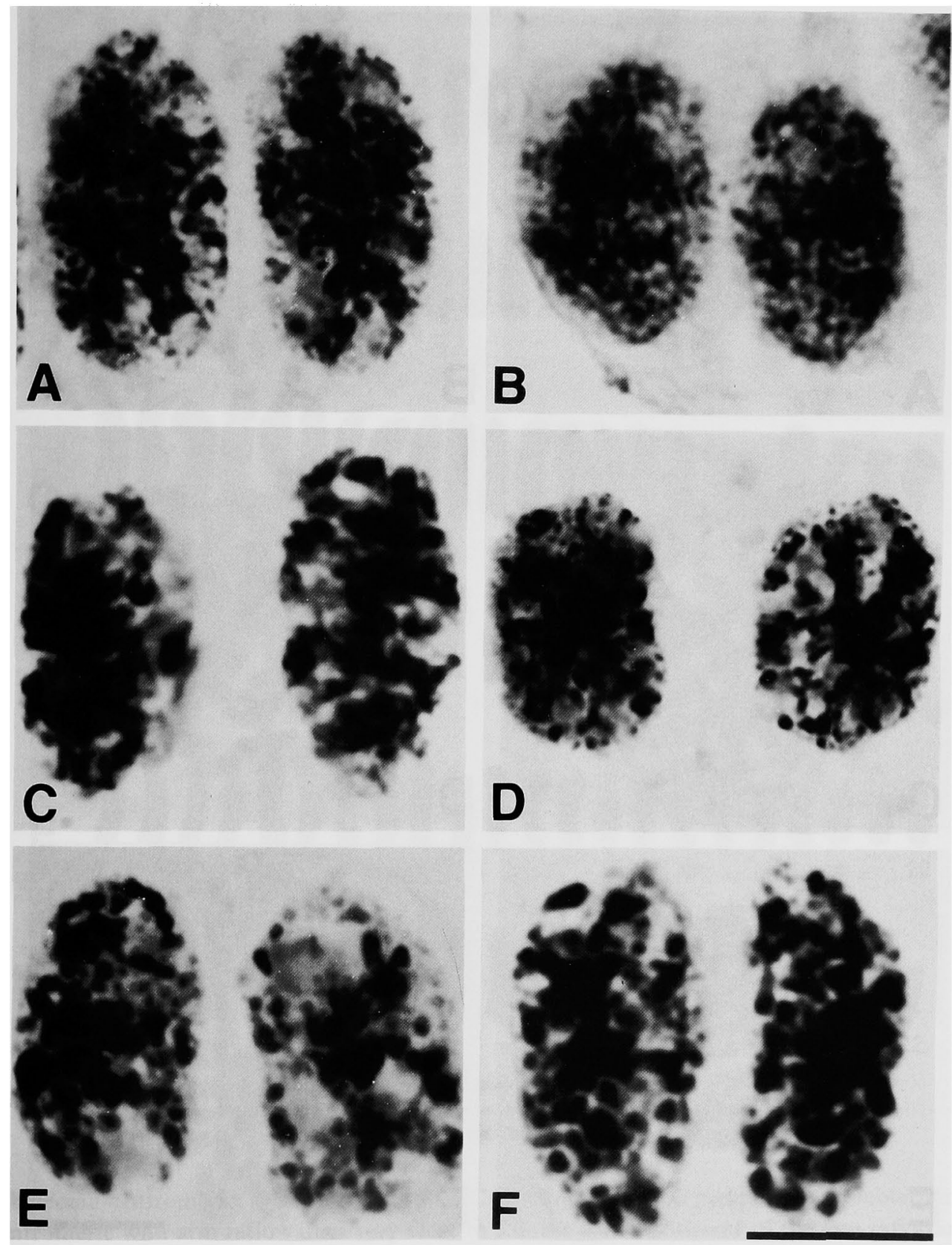

Fig. 1. The chromocenter type of the chromosomes at early interphase in five species and one

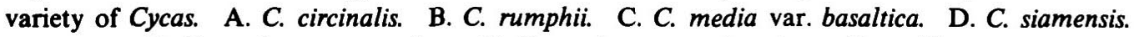
E. C. revoluta var. revoluta. F. C. revoluta var. taiwaniana. Bar $=10 \mu \mathrm{m}$.

iomes positioned according to chromosome length from the 5th (the longest terminal:entromeric) to the 16th (the shortest terminal-centromeric) chromosomes (Table 2). How:ver, respective homologous chromosomes were not easily identified and paired (Table 2). The Irm ratios of respective terminal-centromeric chromosome in 14 mitotic-metaphase complenents of $C$. revoluta var. revoluta studied were unstable. The arm ratios of the 12 terminal- 

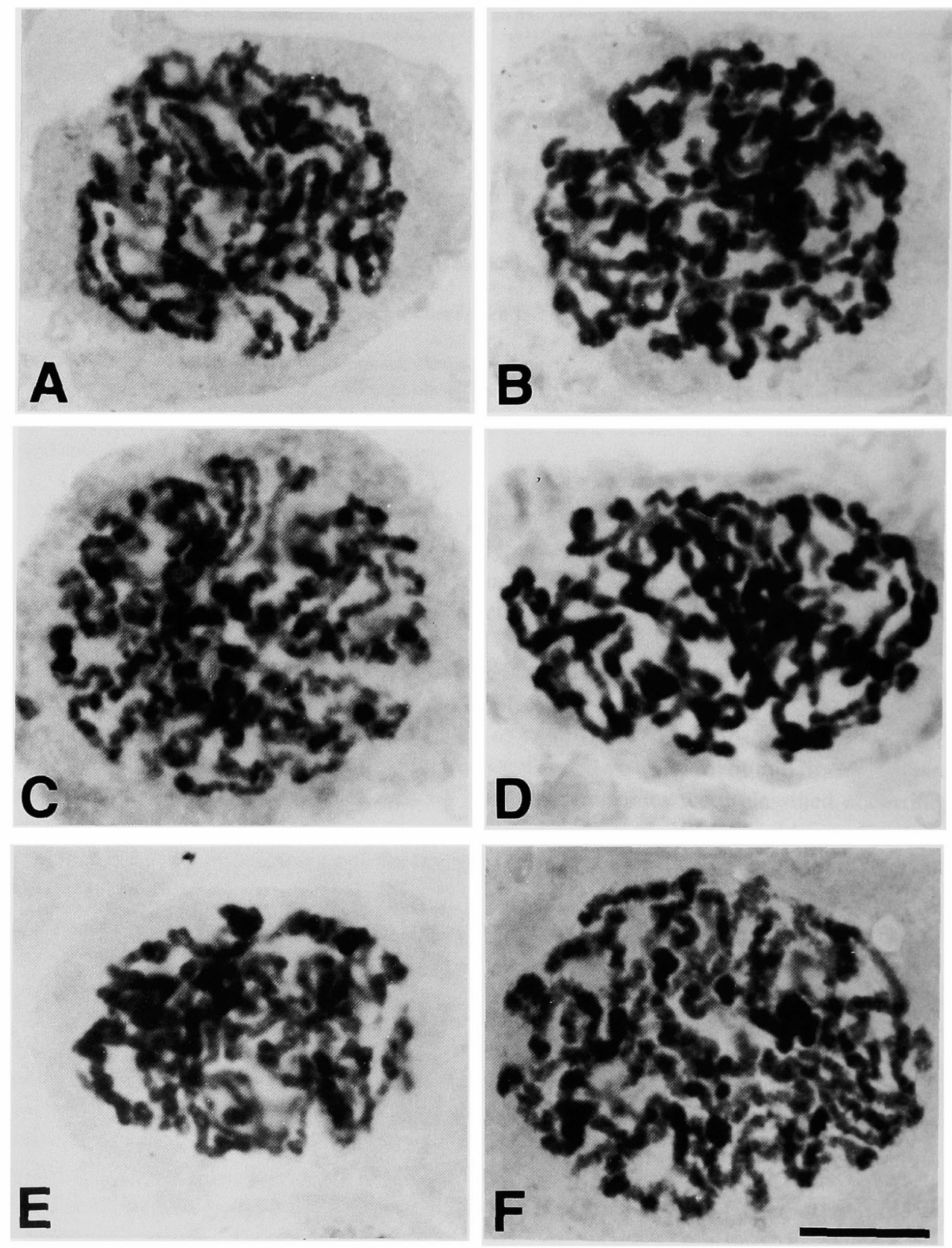

Fig. 2. The interstitial type of the chromosomes at mitotic prophase in five species and one variety of Cycas. A. C. circinalis. $\quad$ B. C. rumphii. C. C. media var. basaltica. D. C. siamensis. E. C. revoluta var. revoluta. F. C. revoluta var. taiwaniana. Bar $=10 \mu \mathrm{m}$.

centromeric chromosomes in C. siamensis were smaller than those of the other taxa (Table 2). These quantitative differences in arm ratio of terminal-centromeric chromosome could not be due to species specificity but be due to condensation of the long and the short arms of chromosome.

The four longest chromosomes in the complements at mitotic metaphase in the taxa were 


\section{Alfirmarementian 15 \\ 16
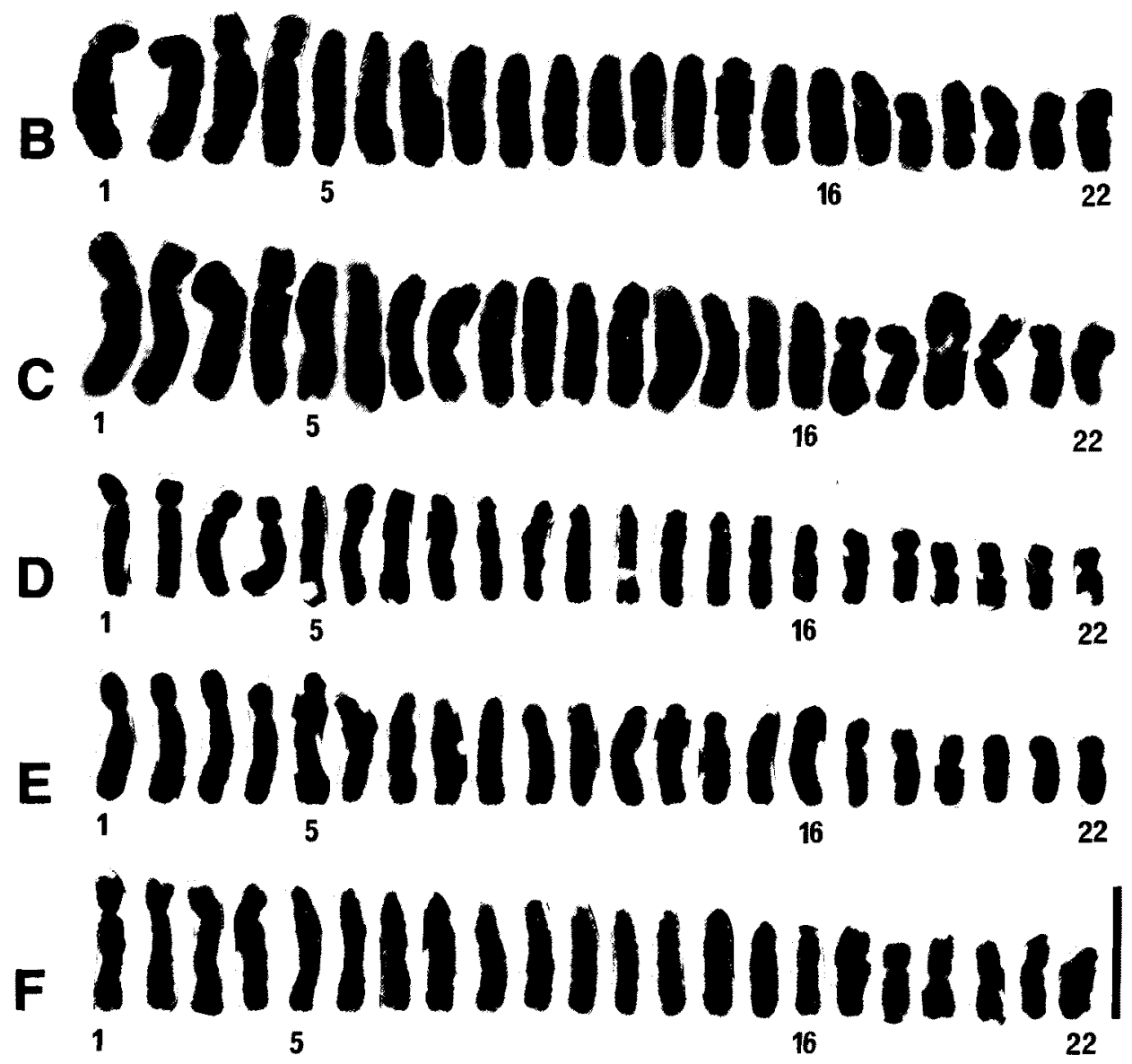

Fig. 3. Karyotypes with $2 n=22$ at mitotic metaphase in five species and one variety of Cycas. A. C. circinalis. B. C. rumphii. C. C. media var. basaltica. D. C. siamensis. E. C. revoluta var. revoluta. F. C. revoluta var, taiwaniana. Bar $=10 \mu \mathrm{m}$.

submedian-centromeric, excepting those in $C$. circinalis and $C$. rumphii were subterminalcentromeric with arm ratio values very close to 3.0, the highest extreme of the arm ratio range of the submedian-centromeric chromosome according to Levan et al. (1964). Selvaraj (1980) said that the pair of the longest chromosomes of $C$. circinalis had secondary constriction. However, the longest chromosomes of either $C$. circinalis or the other taxa studied here showed no secondary constriction. The seventeenth, the $18 \mathrm{th}$, the $21 \mathrm{st}$ and the $22 \mathrm{nd}$ chromosomes in the complements at mitotic metaphase in all of the taxa studied were either median-centromeric or submedian-centromeric. Then, those median-centromeric chromosomes classified had always arm ratio value very close to 1.8 , the lowest extreme of arm ratio range of the submedian-centromeric chromosome according to Levan et al. (1964).

The five species and one variety of Cycas studied showed the stable chromosome number 
Table 2. Mean arm ratios of chromosomes in the complement at mitotic metaphase in five species and one variety of Cycas

\begin{tabular}{lcccccc}
\hline \hline $\begin{array}{c}\text { Chromosome } \\
\text { in order }\end{array}$ & CIR & RUM & BAS & SIA & REV & TAI \\
\hline 1st & $3.2(\mathrm{st})$ & $3.4(\mathrm{st})$ & $3.0(\mathrm{sm})$ & $2.4(\mathrm{sm})$ & $2.9(\mathrm{sm})$ & $2.9(\mathrm{sm})$ \\
2nd & $3.0(\mathrm{sm})$ & $3.2(\mathrm{st})$ & $3.0(\mathrm{sm})$ & $2.5(\mathrm{sm})$ & $2.8(\mathrm{sm})$ & $3.0(\mathrm{sm})$ \\
3rd & $2.8(\mathrm{sm})$ & $3.2(\mathrm{st})$ & $2.7(\mathrm{sm})$ & $2.9(\mathrm{sm})$ & $2.9(\mathrm{sm})$ & $2.9(\mathrm{sm})$ \\
4th & $3.2(\mathrm{st})$ & $2.9(\mathrm{sm})$ & $2.9(\mathrm{sm})$ & $2.8(\mathrm{sm})$ & $2.9(\mathrm{sm})$ & $2.6(\mathrm{sm})$ \\
5th & $14.0(\mathrm{t})$ & $12.3(\mathrm{t})$ & $13.7(\mathrm{t})$ & $8.5(\mathrm{t})$ & $14.1(\mathrm{t})$ & $14.4(\mathrm{t})$ \\
6th & $13.5(\mathrm{t})$ & $12.2(\mathrm{t})$ & $12.0(\mathrm{t})$ & $9.6(\mathrm{t})$ & $13.6(\mathrm{t})$ & $14.0(\mathrm{t})$ \\
7th & $14.4(\mathrm{t})$ & $11.5(\mathrm{t})$ & $11.8(\mathrm{t})$ & $10.5(\mathrm{t})$ & $13.2(\mathrm{t})$ & $13.2(\mathrm{t})$ \\
8th & $12.6(\mathrm{t})$ & $12.1(\mathrm{t})$ & $10.9(\mathrm{t})$ & $8.2(\mathrm{t})$ & $14.0(\mathrm{t})$ & $13.3(\mathrm{t})$ \\
9th & $12.4(\mathrm{t})$ & $11.1(\mathrm{t})$ & $12.5(\mathrm{t})$ & $9.5(\mathrm{t})$ & $13.4(\mathrm{t})$ & $13.3(\mathrm{t})$ \\
10th & $12.3(\mathrm{t})$ & $10.6(\mathrm{t})$ & $11.4(\mathrm{t})$ & $9.0(\mathrm{t})$ & $12.6(\mathrm{t})$ & $12.4(\mathrm{t})$ \\
11th & $12.6(\mathrm{t})$ & $11.0(\mathrm{t})$ & $11.0(\mathrm{t})$ & $10.1(\mathrm{t})$ & $12.5(\mathrm{t})$ & $13.6(\mathrm{t})$ \\
12th & $11.5(\mathrm{t})$ & $11.0(\mathrm{t})$ & $10.9(\mathrm{t})$ & $8.3(\mathrm{t})$ & $12.7(\mathrm{t})$ & $13.6(\mathrm{t})$ \\
13th & $13.0(\mathrm{t})$ & $10.2(\mathrm{t})$ & $11.0(\mathrm{t})$ & $10.8(\mathrm{t})$ & $12.3(\mathrm{t})$ & $13.9(\mathrm{t})$ \\
14th & $10.8(\mathrm{t})$ & $10.7(\mathrm{t})$ & $10.6(\mathrm{t})$ & $8.5(\mathrm{t})$ & $12.2(\mathrm{t})$ & $12.7(\mathrm{t})$ \\
15th & $12.4(\mathrm{t})$ & $10.0(\mathrm{t})$ & $10.1(\mathrm{t})$ & $8.3(\mathrm{t})$ & $11.5(\mathrm{t})$ & $12.0(\mathrm{t})$ \\
16th & $13.3(\mathrm{t})$ & $8.6(\mathrm{t})$ & $10.5(\mathrm{t})$ & $7.2(\mathrm{t})$ & $10.7(\mathrm{t})$ & $10.1(\mathrm{t})$ \\
17th & $1.7(\mathrm{~m})$ & $1.5(\mathrm{~m})$ & $1.8(\mathrm{sm})$ & $1.6(\mathrm{~m})$ & $1.8(\mathrm{sm})$ & $2.0(\mathrm{sm})$ \\
18th & $1.7(\mathrm{~m})$ & $1.5(\mathrm{~m})$ & $1.7(\mathrm{~m})$ & $1.7(\mathrm{~m})$ & $1.8(\mathrm{sm})$ & $2.0(\mathrm{sm})$ \\
19th & $1.0(\mathrm{~m})$ & $1.1(\mathrm{~m})$ & $1.2(\mathrm{~m})$ & $1.5(\mathrm{~m})$ & $1.2(\mathrm{~m})$ & $1.1(\mathrm{~m})$ \\
20th & $1.1(\mathrm{~m})$ & $1.1(\mathrm{~m})$ & $1.2(\mathrm{~m})$ & $1.2(\mathrm{~m})$ & $1.2(\mathrm{~m})$ & $1.1(\mathrm{~m})$ \\
21st & $1.5(\mathrm{~m})$ & $2.0(\mathrm{sm})$ & $1.7(\mathrm{~m})$ & $1.9(\mathrm{sm})$ & $1.6(\mathrm{~m})$ & $1.8(\mathrm{sm})$ \\
22nd & $1.7(\mathrm{~m})$ & $1.8(\mathrm{sm})$ & $1.6(\mathrm{~m})$ & $2.1(\mathrm{sm})$ & $1.6(\mathrm{~m})$ & $1.8(\mathrm{sm})$ \\
\hline Total chromosome & 164.6 & 170.3 & 172.0 & 139.1 & 171.5 & 161.6 \\
length of complement & & & & & \\
\hline
\end{tabular}

$\mathrm{CIR}=C$. circinalis. $\mathrm{RUM}=C$. rumphii. $\mathrm{BAS}=C$. media var. basaltica. $\mathrm{SIA}=C$. siamensis. $\mathrm{REV}=C$. revoluta var. revoluta. TAI $=C$. revoluta var. taiwaniana. $(\mathrm{m})=$ median-centromeric chromosome. $(\mathrm{sm})=$ submedian-centromeric chromosome. $\quad(s t)=$ subterminal-centromeric chromosome. $\quad(t)=$ terminal-centromeric chromosome. Although respective chromosome in order among six taxa had sometimes different chromosome type classified by the ranges of arm ratios proposed by Levan et al. (1964) from each other, their arm ratio values were approximation with each other.

of $2 n=22$ and karyotype, that were quite similar to those of the other cycad-genera except for Zamia which had karyotype variability possibly caused by centromeric fusion and fission (Norstog 1980, Moretti and Sabato 1984, Moretti 1990). Thus, the present result supported Stevenson's hypothesis (1990) that Cycas was a monophyletic group by vegetative and reproductive morphological approaches. Although Schuster (1932) classified Cycas into three sections (Table 1), the present study showed no indication to follow those sections.

\section{Summary}

The chromosomes of five species and one variety of Cycas studied showed commonly the morphological characteristics of the complex chromocenter type at early interphase and the interstitial type at mitotic prophase. All of the taxa had the common chromosome number of $2 n=22$ and very similar karyotypes to each other; $C$. media var. basaltica and $C$. siamensis showed the chromosome number of $2 n=22$ for the first time.

\section{References}

Ishikawa, M. 1916. A list of the number of chromosomes. Bot. Mag. Tokyo 30: 404-448. 
Levan, A., Fredga, K. and Sandberg, A. A. 1964. Nomenclature for centromeric position on chromosomes. Hereditas 52: $201-220$.

Marchant, C. J. 1968. Chromosome patterns and nuclear phenomena in the cycad families Stangeriaceae and Zamiaceae. Chromosoma (Berl.) 24: 100-134.

Moretti, A. 1990. Cytotaxonomy of cycads. Mem. New York Bot. Gard. 57: 114-122.

- and Sabato, S. 1984. Karyotype evolution by centromeric fission in Zamia (Cycadales). Plant Syst. Evol. 146: 215223.

Norstog, K. 1980. Chromosome numbers in Zamia (Cycadales). Caryologia 33: 419-428.

Peng, C. I., Yen, S. F. and Guo, J. Y. 1986. Notes on the chromosome cytology of some rare, threatened, or endangered plants of Taiwan (1). Bot. Bull. Acad. Sinica (Taipei) 27: 219-235.

Sax, K. and Beal, J. M. 1934. Chromosomes of the Cycadales. J. Arnold Arb. 15: 255-258.

Selvaraj, R. 1980. Cytotaxonomical studies on some species of cycads. J. Indian Bot. Soc. 59: $320-324$.

Schuster, J. 1932. Cycadaceae. in A Engler, ed., Das Pflanzenreich 99, Engelmann, Leipzig, pp. 168.

Stevenson, D. W. 1990. Morphology and systematics of the Cycadales. Mem. New York Bot. Gard. 57: 8-55.

Tanaka, R. 1977. Recent karyotype studies, pp. 293-326. in K. Ogawa et al., eds., Plant Cytology, Asakura Book Co., Ltd., Tokyo, pp. 428 (in Japanese). 